\title{
KAIDAH FIQH BIDANG MU'AMALAH MAZHAB SYAFI'I (Kajian Teoritis dan Praktik serta Kehujjahannya)
}

\author{
Sumarjoko, Hidayatun Ulfa \\ STAINU Temanggung \\ sumarjokokusumo@gmail.com
}

\begin{abstract}
The Islamic economic system is believed to be the way of salvation. This will replace the capitalist and socialist economic systems which are considered to be unable to provide a sense of justice and prosperity. To meet and answer the challenge, Islamic jurists (fuqaha) in various layers carried out a methodological study of Islamic law, critical of the manhaj (method) that classical scholars have formulated. The jurists acknowledged, that, legal texts were limited, while new legal cases were constantly developing "An-nushus mutanahiyah wa al-waqa'u ghairu mutanahiyah". On this matter, it is necessary to develop a method (manhaj al-ijtihad) seriously by legal experts, practitioners or shari'ah economists in solving problems related to mu'amalah.

For this reason, ushul fiqh is a procedure of ijtihad as well as a barometer of the jurisprudence of a law. At its climax, ushul fiqh from the beginning to being a formulation of Islamic law continues to get attention related to the principles of general argument. Then created the formulation of al-qawaid al-ushuliyyah and al-qawaid alfiqiyyah. The rule of fiqh is a science that helps mechanically in furu problems. The rules of fiqh are also formulated as a simplifier in the problem of furu' or fiqiyyah. In literacy of Islamic law, between usul rules and fiqh rules sometimes occur intermingling.

Sometimes the rules of usul are not separated in the same discussion with the rules of figh, but each has its own limits and reach. Ushul rules in its application as "Takhrij al-Ahkam" (issuing law from its source), while the fiqh rule is "Tathbiq alAhkam" which applies to cases that arise in human life. The jurisprudence of the rules of fiqh occurred in the Syafi'ah school of khilafiyyah. Nevertheless, it can be classified with the following provisions: first, if the fiqh rule is general (kulli), it can be used as a source of law as nash, ijma and qiyas. Its existence is very significant and can make the argument or proof of matter. Second, if the rule is a majority (aghlabiyah) then it is disputed. On this basis, this study is very important to be further explored.
\end{abstract}

Keyword: Kaidah fikih, muamalah, kehujjahan

\section{Abstrak}

Sistem ekonomi Islam diyakini sebagai jalan keselamatan. Ini akan menggantikan sistem ekonomi kapitalis dan sosialis yang tidak mampu memberikan rasa keadilan dan kemakmuran. Untuk memenuhi dan menjawab tantangan tersebut, para ahli hukum Islam (fuqaha) di berbagai lapisan dilakukan studi metodologis hukum Islam, kritis terhadap manhaj (metode) yang telah dirumuskan para ulama klasik. Para ahli hukum mengakui, bahwa, teks-teks hukum terbatas, sementara kasus-kasus hukum baru terus berkembang "An-Nushus Mutanahiyah wa al-waqa'u ghairu mutanahiyah". Dalam 
Jurnal lqtisad: Reconstruction of Justice and Welfare for Indonesia - Vol. 6, No 1 (2019) p-ISSN: 2303-3223; e-ISSN: 2621-640X

Kaidah Fiqh Bidang Mu'amalah....

hal ini, ini adalah metode (manhaj al-ijtihad) yang serius oleh para ahli hukum, praktisi atau ekonom syariah dalam menyelesaikan masalah yang berkaitan dengan mu'amalah.

Untuk alasan ini, usul fiqh adalah prosedur ijtihad serta barometer yurisprudensi hukum. Pada klimaksnya, ushul fiqh terkait dengan prinsip-prinsip argumen umum. Kemudian dibuat rumusan al-qawaid al-ushuliyyah dan al-qawaid alfiqiyyah. Aturan fiqh adalah ilmu yang membantu secara mekanis dalam masalah furu. Aturan figh juga dirumuskan sebagai penyederhanaan dalam masalah furu' atau fiqhiyyah. Dalam literasi hukum Islam, antara aturan proposal dan aturan fiqh terkadang terjadi pembauran.

Terkadang aturan proposal tidak dipisahkan dalam diskusi yang sama dengan aturan fiqh, tetapi masing-masing memiliki batas dan jangkauannya sendiri. Aturan Ushul dalam penerapannya sebagai "Takhrij al-Ahkam" (mengeluarkan hukum dari sumbernya), sedangkan aturan fikih adalah "Tathbiq al-Ahkam" yang berlaku untuk kasus-kasus yang muncul dalam kehidupan manusia. Yurisprudensi aturan fiqh di sekolah Syafi'ah khilafiyyah. Namun demikian, ini dapat digunakan sebagai sumber hukum seperti nash, ijma dan qiyas, pertama, jika aturan fiqh bersifat umum (kulli). Keberadaannya sangat signifikan dan bisa dijadikan argumen atau pembuktian materi. Kedua, jika aturannya adalah mayoritas (aghlabiyah) maka itu diperdebatkan. Atas dasar ini, penelitian ini sangat penting untuk dieksplorasi lebih lanjut.

Kata kunci: Aturan fikih, muamalah, kehujjahan

\section{A. Pendahuluan}

Pada dekade akhir-akhir ini, ekonomi syariah mulai banyak diperbincangkan publik. Baik secara akademisi ataupun praktisi. Baik secara lokal ataupun nasional, bahkan secara trans-nasional. Banyak pihak mengakui, perkembangan ekonomi syariah telah mencapai puncaknya untuk diyakini sebagai jalan keselamatan ekonomi umat manusia dan menggantikan ekonomi kapitalis dan sosialis yang dirasa kurang mampu memberikan rasa keadilan dan kesejahteraan umat.

Dilingkungan praktisi, banyak pula ekonom perbankan konvensional, yang mulai melirik perbankan syariah. Hal ini ditandai dengan munculnya bank-bank syariah yang lahir dari rahim bank konvensional. Berbagai upaya dilakukan oleh masing-masing pihak manajemen untuk menjadi muallaf, yakni sistem perbankan syariah demi mempertahankan dan memberikan kepuasan kepada nasabah. Ditambah lagi, viral-nya adanya fatwa haram terhadap bunga bank diberbagai media. Hal ini sangat mempengaruhi keyakinan konsumen untuk menjauhkan diri dari haramnya bunga bank konvensional. Untuk itu, banyak para nasabah muslim yang mulai menjauhi perbankan 
Jurnal lqtisad: Reconstruction of Justice and Welfare for Indonesia - Vol. 6, No 1 (2019)

Kaidah Fiqh Bidang Mu'amalah....

konvensional dengan cara memindahkan deposito ataupun investasi lainnya ke perbankan syariah. Untuk itu persoalan menjadi serius terhadap perbankan di Indonesia.

Di sisi lain, berdirinya perbankan syariah, koperasi syariah, dan lembaga keuangan syariah lainnya, telah menggerakkan para ahli hukum Islam (fuqaha) untuk mengadakan pengembangan pemikiran hukum Islam terkait dengan kebutuhan yang harus dipenuhi terhadap segala pesoalan yang ada pada ekonomi perbankan syariah. Untuk memenuhi dan menjawab tantangan itu, para ulama diberbagai lapisan telah berusaha melakukan kajian-kajian hukum Islam secara metodologis yang kritis atas manhaj (metode) yang sebelumnya pernah digunakan oleh para ulama klasik dibidang ilmu ushul fiqh ataupun kaidah fiqh.

Di lingkungan akademisi, para ahli hukum Islam (fuqaha) banyak melakukan kajian-kajian ekonomi syari'ah secara intens. Melalui acara seminar, workshop, ataupun kajian ilmiah lainnya, para ahli mulai membolak-balikan literasi arab klasik (turats) untuk mencari teks-teks hukum yang terkait dengan ekonomi syariah. Kajian demi kajian tak pernah terhenti, namun hasil akhirnya tetap sama dengan kesimpulan sebelumnya, bahwa literasi hukum belum memadai terhadap persoalanpersoalan kekinian yang dihadapi umat Islam untuk mewarnai ekonomi syariah. Para ahli hukum Islam (fuqaha) mengakui dan menegaskan, bahwa, teks-teks hukum itu terbatas adanya, sedangkan kasus-kasus hukum yang baru senantiasa berkembang "An-nushus mutanahiyah wa alwaqa'u ghairu mutanahiyah". ${ }^{1}$ Dengan demikian gerakan yang massiv dari ekonomi perbankan konvensional yang mengarah ke ekonomi syariah membutuhkan pemikiran yang serius oleh para ahli dan praktisi ekonom syari'ah. Bila hal ini tidak diimbangi dengan pembaharuan-pembaharuan (tajdid) dalam hukum Islam yang terkait dengan ekonomi perbankan syari'ah maka kesempatan emas ini akan meredup, dan ekomoni syari'ah akan dianggap tidak mampu mengikuti perkembangan zaman. Padahal, ilmu fiqh yang didalamnya terkandung ekonomi (mua'amalah) adalah salah satu ilmu dalam Islam yang paling dinamis, elastis dan responsif diantara ilmu keislaman yang lain. Bila sebaliknya yang terjadi, saat ilmu fiqh jumud (tidak dapat berkembang), rigid atau kaku sehingga tidak

${ }^{1}$ Al-Syahratsani, Al-Milal wa an-Nihal, Juz.i, (Mesir: Matba'ah Musthafa alBabi al-Halabi wa Auladuh, 1967), 199. Dikutip oleh Syamsul Anwar, Argumentum a Fortiori dalam Metode Penemuan Hukum Islam, Studi Hukum Islam: Kajian Tematik Terhadap Persoalan Kontemporer, (Jogjakarta: Fakultas Syari'ah Press UIN Sunan Kalijaga, 2008), 106. 
Jurnal lqtisad: Reconstruction of Justice and Welfare for Indonesia - Vol. 6, No 1 (2019)

responsif terhadap persoalan waqi'iyah maka citra Islam sebagai agama rahmatan lil 'alamin' akan kehilangan ruh kemaslahatannya.

Disamping ilmu fikih yang dinamis, elastic dan responsif terhadap kemaslahatan umat, maka ushul fikih juga merupakan bagian ilmu yang menduduki tempat yang utama. Dalam ilmu keislaman, ushul fikih sebagai prosedur ijtihad sekaligus barometer terhadap kehujahan suatu produk hukum. Pada saat mencapai titik klimaknya dasar-dasar fikih tersebut, para ahli hukum "fuqaha" mengembangkan ilmu ini dengan upaya penyederhanaan dengan merumuskan kaidah-kaidah umum yang membantu dalam menetapkan suatu hukum. Kaidah-kaidah tersebut akhirnya dikenal sebagai kaidah ushul "qaidah ushul". Selain dikembangkannya kaidah ushul, juga dikembangkan pula kaidah-kaidah fikih atau qawaid al-Fiqqiyah.

Kaidah Fiqh merupakan ilmu yang membantu secara mekanis dalam masalah-masalah furu'. Kaidah fiqh juga dirumuskan untuk menyederhanakan dalam masalah furu' atau fiqiyyah. Dalam literasi hukum Islam, kedua kaidah ini terkadang saling membaur dalam artian terkadang kaidah ushul tidak terlepas dalam bahasan yang sama dengan kaidah fiqh meskipun demikian masing-masing memiliki batasan dan jangkauan tersendiri. Ulama yang pertama kali membedakan antara kaidah ushul dan kaidah fikih adalah Syihabuddin al-Qarafi (w.684) dalam kitabnya al-Furuq. ${ }^{3}$ Kaidah ushul dalam penerapanya sebagai Takhrij alAhkam (mengeluarkan hukum dari sumbernya), sedangkan kaidah fikih adalah Tathbiq al-Ahkam yang penerapannya pada kasus-kasus yang timbul dalam kehidupan manusia. Kaidah fikih berkembang pesat sesuai dengan budaya dan peradaban manusia pada tiap masanya.

Saat ini, literasi kaidah fiqh terus terus berkembang secara signifikan dari masa ke masa. Bahkan, telah terkumpul mencapai angka seribuan. Oleh karena itu, untuk memudahkan sebaran kaidah tersebut, maka para ulama yang keahliannya dibidang hukum banyak yang menulis kaidah-kaidah fiqh dalam bidang tertentu. Semisal kaidah fiqh khusus dalam bidang ibadah mahdhah, siyasah, qadla (peradilan) jinayah, munakahat, mu'amalah dan lainnya. ${ }^{4}$

\footnotetext{
2 Al-Qur'an, surat al-Anbiya' : 107.

${ }^{3}$ Said Aqil al-Munawwar," Al-Qawaid al-Fiqiyyah dalam Perspektif Hukum Islam", al-Jami'ah :Jurnal of Islamic Studies, No. 62/XII/1998, state Institut of Islam Studies( IAIN) Sunan Kali Jaga. hlm.102.

4 H.A. Djazuli, 2014, Kaidah-Kaidah Fikih: Kaidah-Kaidah Hukum Islam dalam Menyelesaikan Masalah-masalah yang Praktis, Kencana Prenadamedia Group, Jakarta, hlm. 114-161.
} 
Dari beberapa bidang fikih tersebut, maka bidang fiqh mu'amalah atau ekonomi syariah menduduki tingkat tertinggi kebutuhannya terhadap teks-teks hukum. Setiap terjadi perubahan kebijakan ekonomi, baik skala nasional ataupun trans-nasional, munculnya transaksi perdagangan berbasis elektronika, pembaruan aktifitas perdagangan manusia, munculnya inovasi produk baru, inovasi jenis transaksi, dan inovasiinovasi bidang ekonomi lainya pasti membutuhkan kejelasan dan dukungan teks hukum. Oleh karena itu, dalam penelitian ini, penulis merasa penting untuk melakukan kajian terhadap perkembangan kaidahkaidah fiqh yang terkait fiqh mua'amalah serta penerapannya.

\section{B. Kajian umum}

\section{Definisi Kaidah Fiqh}

Ahli fiqh (fuqaha) merumuskan definisi kaidah fiqh dengan bahasa yang berbeda-beda meskipun subtasnsinya adalah sama.

Imam Tajjuddin as-Subki (w.771 H.) mendefinisikan suatu yang bersifat umum yang meliputi bagian yang sangat banyak, yang dapat dipahami hukum bagian tersebut dengan kaidah yang terkait. ${ }^{5}$ Sedangkan Abu Zahrah mendefinisikan, Sekumpulan hukum-hukum yang serupa yang kembali pada qiyas yang mengumpulkannya. ${ }^{6}$ As-Suyuthi (w.911 H) mendefiinisikan, hukum kulli (general) yang meliputi bagian-bagiannya. ${ }^{7}$ Dan masih banyak definisi yang lain yang secara subtansi adalah sama.

Kata kaidah fiqh merupakan susunan dua kata yang bersumber dari bahasa Arab al-qa'idah yang secara etimologi memiliki arti asas, dasar, fondasi dengan bentuk al-qawa'id yaitu, serangkain kaidah-kaidah. Sedangkan secara etimologi al-fiqh berarti al-fahm atau faham. Tidak masalah apakah faham itu sifatnya sekilas atau mendetail meskipun demikian yang diharapkan kefahaman tersebut adalah yang mendetail. Sebagian fuqaha -ahli fiqh- membahasnya dalam satu bahasan dengan ushul fiqh dan sebagian yang lain membahas secara tersendiri.

Kaidah fiqh dipisahkan dengan ushul fiqh karena ada argumentasi tersendiri. Ushul fiqh adalah suatu metodologi yang

${ }^{5}$ Al-Imam Tajjuddin Abdul Wahab bin Ali bin Abdul Kafi as-Subki, al-Asybah wa an-Nazhair, (Beirut: Dar al-Kutub al-Islamiyyah, tt ) Juz I, hlm. 11.

${ }^{6}$ Muhammad Abu Zahrah, Ushul Fiqh( tt. Dar al-Fikri al-Arabi, t.t.) hlm. 10.

${ }^{7}$ Al-Suyuthi, Jalaluddin, Abd al-Rahman, al-Asybah wa an-Nazhair: Fi Qawaid wa Furu' fiqh asy-Syafi'i, cet. I(Beirut: Dar al-Kutub al-Ilmiyyah, 1979) hlm.5. 
tujuan dan fungsinya adalah takhri al-ahkam dengan melalui istidlal, istinbat dan yang terberat lagi adalah ijtihad. Sedangkan kaidah fiqh sifatnya adalah menyederhanakan masalah-masalah cabang -furu'yah- yang serupa dan sebanding menjadi suatu rumusan sederhana yang mudah dipahami. Adakalanya penyerdehanaan dari hal-hal furu' yang serupa dan sebanding ini didapatkan dari materi-materi fiqh yang sudah tertuang dalam kitab-kitab fiqh. Dimungkinkan juga perumusan kaidah disusun melalui persoalan-persoalan yang dilakukan mukallaf secara umum, baik yang telah terjadi atau yang baru terjadi untuk disimpulkan menjadi suatu rumusan kaidah.

\section{Sejarah Perkembangan Kaidah Fiqh}

Munculnya literasi kaidah fikih pada awalnya disinyalir oleh sebagian ahli hukum bersumber dari teks-teks hadis Nabi Muhammad yang menggunakan kalam yang singkat ${ }^{8}$ dan mengandung makna yang luas atau jawami' al-Kalim. ${ }^{9}$ Meskipun demikian sebagaimana yang dikutip oleh as-Suyuthi dalam kitabnya al-Asybah wa anNazhair: fi Qawaid wa furu' Figh Syafi'i, penyusun literasi kaidah pertama diperkirakan adalah ulama bermazhab Hanafiyyah, Abu Thahir al-Dabbas yang mengumpulkan 17 butir kaidah. ${ }^{10}$ Para ulama Hanafiyah mengembalikan persoalan fiqih pada kaidah-kaidah tersebut. Kemudian literasi kaidah fiqh diikembangkan ulama Syafi'iyyah semisal Abu Said al-Harawi (w.488 H). Pada awalnya, perkembangan kaidah fiqh relatif lambat, bahkan hanya terjadi penambahan sekitar 20 butir dalam waktu satu abad sebagaimana yang dikembangkan Imam Abu Hasan al-Karkhi. Perkembangan kaidah fikih mulai meningkat drastis sekitar abad ke-5 Hijriyyah.

Dalam mazhab as-Syafi'i, seorang ulama terkemuka (Sulthanu al-Ulama), Imam Izzuddin ibn Abd al-Salam (w.660 H.) telah menyusun kitab dengan judul Qawaid al-Ahkam fi Mashalih al'Anan, telah menjelaskan tentang maksud Allah mensyari'atkan

\footnotetext{
${ }^{8}$ Semisal sabda Nabi, "Laa dharara wala dhirara” demikian pula "al-Kharaj bi al-Daman"

${ }^{9}$ Said Aqil al-Munawwar, "Al-Qawaid al-Fiqiyyah dalam Perspektif Hukum Islam", al-Jami'ah :Jurnal of Islamic Studies, No. 62/XII/1998, state Institut of Islam Studies ( IAIN) Sunan Kali Jaga. 1998, 104.

${ }^{10}$ Al-Suyuthi, Jalaluddin, Abd al-Rahman, al-Asybah wa an-Nazhair: Fi Qawaid wa Furu' fiqh asy-Syafi' $i$, cet. I(Beirut: Dar al-Kutub al-Ilmiyyah, 2012) hlm.29.
} 
hukum. Intisari dari dari kitab tersebut, pengarang (autor) mengembalikan semua kaidah fiqh pada satu kaidah pokok (inti) dalam bentuk satu rumusan umum yang sederhana tetapi meliputi semua aspek bagianya.

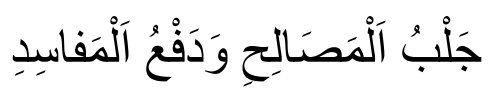

Meraih maslahah dan menolak mafsadah

Mengikuti keseluruhan "taklif" (beban hukum) yang tercermin dalam konsep al-ahkam al-khamsah (hukum yang lima: wajib, sunnah, mubah, makruh dan haram) pada hakikatnya kembali pada kemaslahatan manusia di dunia dan akhirat. Sebaliknya, mengingkari ataupun mendurhakai hukum tersebut adalah bentuk kemaksiatan yang akan merugikan manusia.

Imam Abd Wahab ibn Ali ibn Tamam al-Subki yang lebih tersohor dengan nama Tajjuddin as-Subki (w.771 H.) dalam kitabnya al-Asybah wa al-Nazhair mengemukakan poin-poin kaidah-kaidah pokok kemudian diikuti dengan kaidah-kaidah fiqh umum yang penting (al-Qawaid al-'Ammah) dan tidak terbatas pada persoalan tertentu. Pengarang (uator) juga membahas al- Dhawabith alFiqiyyah yang disebut Al-Qawaid al-Khashah sebagai turunan kaidah asasi.

Muhammad ibn Bahadur ibn Abdullah Badruddin al-Zarkasyi (w.794 H.) dalam kitabnya, Al-Manshur fi Tartib al-Qawaid fi alFuru' telah menghimpun kurang lebih 100 kaidah yang sangat rinci disertai dengan dhabith-nya.

Jalal al-Din Abd al-Rahman ibn Abi Bakar ibn Muhammad alSuyuthi (w.911 H.) dalam kitabnya, al-Asybah wa an-Nazhair: Fi Qawaid wa Furu' fiqh asy-Syafi 'i, telah mengemukakan lima kaidah asasi dengan kaidah-kaidah turunannya serta dikuatkan dengan dalildalil sandaran yang rajih dengan pembahasan yang sangat mengesankan. Pengarang (autor) juga mengemukakan kaidah-kaidah yang masih ikhtilaf baina al-Ulama.

Adapun penelitian dalam konteks keindonesiaan yang dilakukan oleh beberapa penulis yang bidang memiliki kualifikasi dalam hukum Islam diantaranya adalah, H.A. Djazuli, 2014, dalam bukunya, Kaidah-Kaidah Fikih: Kaidah-Kaidah Hukum Islam dalam Menyelesaikan Masalah-masalah yang Praktis. Penulis membahas lima kaidah dasar (asasi), melanjutkan pada bahasan kaidah-kaidah yang berskala umum, kaidah-kaidah khusus, juga membahas kaidah- 
kaidah berskala prioritas dan dikahiri dengan kaidah-kaidah dalam skala perkembangan.

Penelitian selanjutnya dilakukan oleh Jaih Mubarok dalam bukunya, Kaidah Fikih: Sejarah dan Kaidah Asasi. Sebagaimana judul buku tersebut, penulis menjelaskan sejarah perkembangan kaidah fikih yang meliputi, sejarah, sumber dan pembagian. Penulis juga menjelaskan lima kaidah-kaidah asasi, namun sebagaimana para penulis sebelumnya yang tidak membahas kadah-kaidah fiqh secara khusus terkait dengan fiqh ekonomi perbankan syari'ah. Untuk itu, peneliti menganggap sangat penting untuk melakukan penelitian tentang kaidah-kaidah fiqh yang secara teknis berkaitan dengan persoalan yang dibutuhkan umat Islam untuk menopang ekonomi perbankan syari'ah di Indonesia. Disamping itu, yang lebih urgen lagi, peneliti juga akan melakukan kajian kritis terhadap kaidahkaidah fiqh yang secara khusus dalam bidang ekonomi syari'ah.

\section{PEMBAHASAN}

\section{Kaidah Asasi}

Kaidah asasi (mendasar) merupakan satu tingkat dibawah "kaidah inti". Kaidah asasi ini dalam mazhab Syafi'i terdapat lima untai. Kaidah tersebut biasa disebut al-qawaid al-khamsah atau lima kaidah yang sifatnya mendasar dan bersandarkan secara langsung pada dalil nash, baik al-Qur'an dan as-Sunnah ataupun ijma'.

a. Kaidah pertama

$$
\text { الأمور بمقاصدها11 }
$$

segala sesuatu persoalan didasarkan pada maksudnya.

Dalam mazhab ulama Syafiiyah, niat itu diartikan dengan bermaksud untuk melakukan "sesuatu" disertai dengan pelaksanaanya. Semisal niat shalat didalam hati disertai dengan gerakan takbirat al-ihram. Kendati demikian, dalam mazhab Hanabillah, niat itu didahulukan karena niat ada

\footnotetext{
${ }^{11}$ Al-Suyuthi, Jalaluddin, Abd al-Rahman, al-Asybah wa an-Nazhair: Fi Qawaid wa Furu' fiqh asy-Syafi'i, cet. I(Beirut: Dar al-Kutub al-Ilmiyyah, 2012) hlm.30.
} 
didalam hati. Jadi beriktikad didalam hati itu sudah cukup dan harus didahulukan dari pada perbuatan. ${ }^{12}$

b. Kaidah kedua

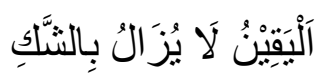

Keyakinan tidak dapat dihilangkan dengan keraguan

Kaidah ini berhubungan erat dengan metode istishab dalam masalah ushul fiqh. Istishah yang didefinisikan untuk mengambil sesuatu yang telah diyakini karena pernah dilakukan dimasa lalu secara konsiten sampai masa selanjutnya atau menetapkan suatu hukum berdasarkan apa yang telah terjadi sebelumnya.

c. Kaidah ketiga

\section{Kemadharatan harus dihilangkan}

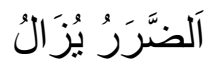

Sesuatu perkara yang mafsadah itu berdampak kerusakan sedangkan kemaslahatan selalu membawa kesejahteraan.Berdasarkan analisa lapangan dan kenyataan di berbagai persoalan yang terjadi secara terulang-ulang, Ibn Abdussalam mengambil suatu kesimpulan dalam bentuk formulasi umum yang hingga saat ini belum terbantahkan sebagaimana dalam pembahasan awal tentang kaidah inti. ${ }^{13}$

d. Kaidah keempat

Kesulitan mendatangkan kemudahan

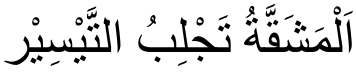

Al-masyaqah secara etimologi adalah at-ta'ab yang berarti kelelahan, kesulitan, dan kesukaran. Adapun at-taisir berarti kemudahan. Kaidah memformulasikan, hukum-hukum yang dalam pelaksanaanya sangat menyulitkan bagi mukallaf maka syariah meringankan sehingga mukallaf mampu melaksanakaanya.

e. Kaidah kelima

Kebiasaan dapat dijadikan dasar hukum

\footnotetext{
${ }^{12}$ Ibn Qudamah, al-Mughni, juz I (ttp: Maktabah Riyadh al-Haditsah, tt) hlm. $111,113$.

${ }^{13}$ Kaidah inti yang dimaksud adalah, Jalbu al-Mashalihi wa daf'u al-Mafasidi.
} 
Secara etimologi, kata " 'adat" memiliki arti "berulang" atau "atTakrir". Kaidah ini menformulasikan, suatu yang dilakukan secara terulang-ulang itu dapat menjadi ketetapan hukum. Untuk itu 'adat dikaji secara tafshili (rinci). "Adat yang "fasid" (bertentangan syara') tidak dapat menjadi pertimbangan dalam menetapkan hukum.

\section{Kaidah Fiqh Umum yang Terkait dengan Fiqh Muamalah}

a.

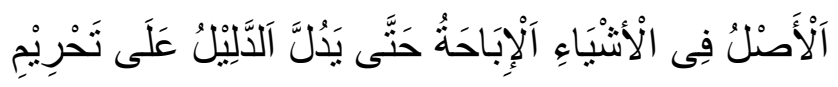

"Pada dasarnya segala sesuatu itu boleh kecuali ada dalil yang mengharamkan"

Berkaitan dengan fikih mua'amalah, atas dasar keumuman kaidah ini, segala bentuk transaksi yang diciptakan manusia adalah boleh kecuali ada dalil yang melarangnya.

b.

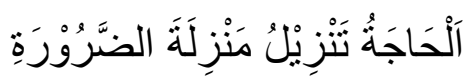

"Keperluan itu dapat menduduki posiisi darurat." Secara umum suatu akad itu dianggap sah apabila rukun dan syarat terpenuhi. Meskipun demikian untuk memenuhi kebutuhan atau hajat manusia. Maka tujuan syariah memberikan kemaslahatan umat manusia. Oleh karena itu syariah memberikan kemudahan dalam suatu akad tertentu yang objeknya belum terwujud. Semisal bolehnya akad "salam" yang hanya menyebutkan ukuran dan sifatsifat objek yang dipesan.

c.

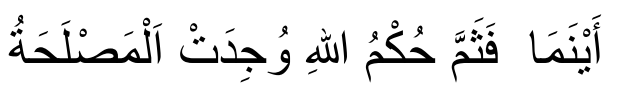

"Dimana terdapat kemaslahatan disana terdapat hukum Allah" Dalam sistem pencatatan dan laporan keuangan (akuntansi) terdapat dua sistem yang masing-masing memiliki kekurangan dan kelebihan. Oleh karena itu, LKS boleh menggunakan prinsip akuntansi yang mengharuskan pengakuan biaya dan pendapatan pada saat terjadinya (cash basis) atau LKS tersebut menggunakan prinsip akuntansi yang membolehkan 
pengakuan biaya dan pendapatan dengan didistribusikan beberapa periode (occrual basis). Kaidah diatas menunjukkan prinsip kemashlahat-an itulah yang paling ideal dan memberikan rasa keadilan. $^{14}$

d.

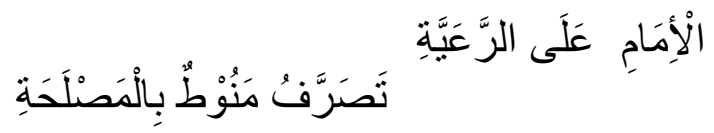

"Tindakan pemimpin (pemegang otoritas) terhadap rakyat harus mengikuti kemashlahatan”. Berdasarka kaidah ini, suatu keharusan bagi Bank Indonesia (BI) dan Otoritas Jasa Keuangan (OJK) untuk melakukan pembinaan, pengawasan dan pengembangan serta perlindungan terhadap Lembaga Keuangan Syariah (LKS) terkait ancaman moneeter.

\section{Kaidah Fiqh dalam Bidang Muamalah}

a.
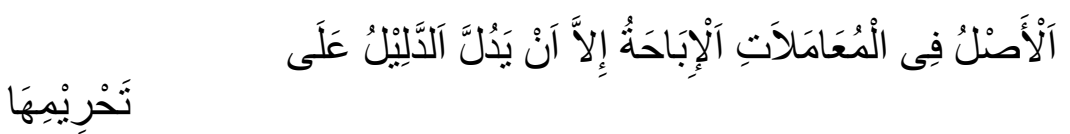

"Pada dasarnya semua bentuk mu'amalah itu boleh kecuali ada dalil yang mengharamkannya".

Kaidah ini dapat diterapkan pada perkembangan transaksitransaksi kekinian. Semisal bursa efek syari'ah. Pada dasarnya efek syariah di pasar sekunder diperbolehkan. Bursa efek merupakan bagian dari fiqh mu'amalah sehingga hukum asalnya adalah diperbolehkan.

b.<smiles>[Al]=[Al]=[Al]</smiles>

\section{"Resiko sebanding dengan manfaat"}

Kaidah ini digunakan terkait pada penjaminan pengembalian modal pada pembiayaan mudharabah, musyarakah, dan wakalah bil istismar. Transaksi mudlarabah itu dibentuk atas dasar amanah, maka pemilik modal tidak boleh meminta pada pengelola untuk menjamin pengembalian modal. Apabila

${ }^{14}$ DSN-MUI, Modul Pelatihan DPS Syariah Koperasi Syariah (Jakarta: tnp, 2018), 164. 
transaksi mudlarabah tersebut mengalami kerugian maka berdasarkan kaidah diatas maka pengelola tidak wajib mengembalikan modal secara penuh.

c.

بَلَا إِذَنِهِ

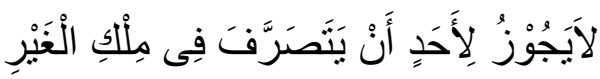

"Tidak boleh menjalankan harta orang lain tanpa seizinnya" berdasarkan kaidah ini, seorang penjual harus pemiliki barang. Oleh karena itu dilarang melakukan bai' al-Ma'dum. Atau melakukan penjualan atas barang (efek syari'ah) yang belum dimiliki (shart selling). ${ }^{15}$

d.

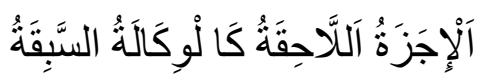

"Izin yang datang kemudian sama kedudukannya dengan perwakilan yang telah dilakukan terlebih dahulu". Kaidah ini berkaitan dengan kaidah sebelumnya. Pada awalnya, seseorang tidak dibolehkan menjual harta orang lain tanpa ijin pemiliknya. Meskipun demikian apa bila terlanjur menjual barang tanpa seijin pemilik dan pemilik akhirnya mombolehkan maka berdasakan kaidah ini maka transaksi tersebut telah sah.

e.

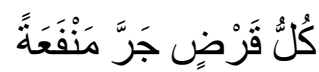

\section{فَهْهُ ربَاب}

"Setiap hutang piutang yang mendatangkan manfaat (bagi piutang/muqaridh) adalah riba". Kiadah ini memiliki cakupan yang luas. Lembaga Keuangan Syariah (LKS) adalah lembaga komersil yang menunjang peningkatan perekonomian umat. Dalam akad qardh, yaitu akad pinjaman kepada nasabah dengan ketentuan bagi nasabah harus mengembalikan pinjaman yang diterima dari LKS sesuai akad yang disepakati. Berdasarkan kaidah ini, LKS tidak boleh mengambil

${ }^{15}$ DSN-MUI, Modul Pelatihan DPS Syariah Koperasi Syariah (Jakarta: tnp, 2018), 167. 
keuntungan dari nasabah. Untuk memenuhi rasa keadalilan, maka nasabah dibebankan pada biaya administrasi.

f.

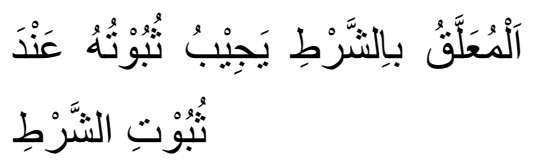

"Yang dikaitkan (janji) dengan syarat wajib dipenuhi apabila syaratnya terpenuhi" Kaidah ini dapat diterapkan pada persoalan target kinerja karyawan. Misalkan seorang marketing diberikan motivasi kinerja dalam bentuk target capaian dengan imbalan insentif. Apabila seorang karyawan diberi janji akan mendapatkan reword berupa uang senilai Rp. 10.000.000,00 apabila berhasil menjualkan 10 unit sepeda motor tiap bulan dalam jangka satu satu tahun. Maka apa bila hal tersebut terpenuhi maka karyawan tersebut harus mendapatkan insentif yang dijanjikan.

g.

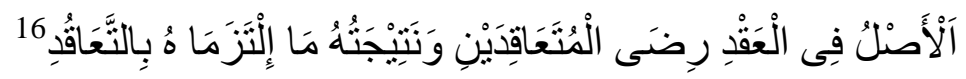

"Hukum ashal transaksi itu keridhaan kedua belah pihak yang berakad, hasilnya adalah berlaku sahnya yang diakadkan."

Berdasarkan kaidah ini, tidak dianggap sah suatu akad apabila salah satu pihak dibawah tekanan pihak lain, atau terjadi unsur keterpaksaan dalam akad tersebut. h.

\section{"Akad yang batal tidak menjadi sah karena dibolehkan"}

Dalam hukum Islam, suatu akad yang bathal maka dianggap tidak pernah terjadi adanya akad. Lembaga Keuangan Syariah (LKM) tidak boleh melakukan transaksi dengan bank konvensional yang menggunakan suku bunga, meskipun bunga dibolehkan oleh pihak lain. ${ }^{17}$

i.

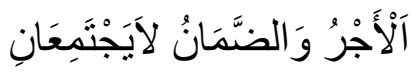

${ }^{16}$ Ahmad al-Nadawi, al-Qawaid al-Fiqhiyah, Cet. V, (Beirut: Dar al-Qalam, 1998), 253.

${ }^{17}$ A. Djazuli, Kaidah-kaidah fikih: Kaidah-kaidah hukum Islam dalam menyelesaikan masalah-masalah yang praktis, (Jakarta: Kencana Prenada Media Group, 2006), 131-132. 
"Pemberian upah dan tanggung jawab untuk mengganti kerugian tidak berjalan bersamaan". Kaiadah ini dapat terapkan dalam kasus sewa menyewa. Semisal, seseorang menyewa mobil jenis penumpang, namun digunakan untuk mengangkut barang dengan beban berat sehingga terjadi kerusakan. Berdasarkan kaidah ini, penyewa harus memperbaiki (ganti rugi / ongkos kerusakan) dan tidak perlu membayar ongkos sewa. $\mathrm{j}$.

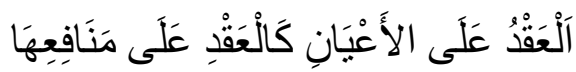

"Akad yang objeknya suatu benda tertentu adalah seperti akad terhadap manfaat benda tersebut" Objek suatu akad itu dapat berupa jual beli barang untuk atau sewa menyewa. Bahkan berupa jasa seperti broker.

$\mathrm{k}$.

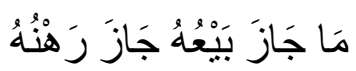

"Apa yang boleh dijual boleh juga digadaikan." Kebanyakan barang yang bisa dijual, bisa pula digadaikan. Semisal, motor, mobil dan lainya. Meskipun demikian terdapat pula pengecualian. Semisal pohon kayu jati atau lainnya yang masih tertanam bisa dijual akan tetapi tidak bisa disewakan karena tidak bisa dipindah atau diambil manfaatnya.

1 .

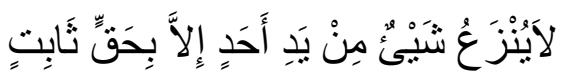

"Sesuatu benda tidak bisa dicabut dari tangan seseorang kecuali atas dasar hukum yang telah tetap." Kaidah ini berlaku pada akad murabbahah di LKS. Seorang debt collector suatu LKS tidak boleh semena-mena merampas motor dari nasabah disebabkan telat bayar atau menuunggak kecuali membawa bukti sertifikat fidusia. Sertifikat fidusia tersebut didasarkan pada Undang-undang nomor 42 tahun 1999.

m.

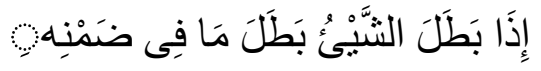

"Apabila suatu akad batal maka batal pula apa yang ada dalam genggamannya" 
Kaidah ini banyak diterapkan pada akad jual beli. Semisal antara penjual dan pembeli terjadi akad "ijab" dan "qabul" atas suatu barang sehingga terjadi serah terima. Kemudian diketahui ternyata pihak penjual bukan orang yang cakap hukum (safih/bodoh) "bukan ahliyyah wujub al-kamilah"18 sehingga akad tersebut dihukumi batal dan pihak pembeli harus mengembalikan barang dan mengambil uangnya kembali.

\section{Kehujjahan Kaidah Fiqh}

Kaidah ushul dan kaidah fiqh merupakan dua hal yang berbeda. Baik penggunaan ataupun cakupannya. Terkadang dua kaidah ini dikaji secara bersamaan dalam ilmu ushul figh. Keduanya disinyalir hampir sama, sehingga terkesan kaidah ushul dan sekaligus berlaku sebagai kaidah fiqh. Namun hal ini menimbulkan tidak mungkinnya terjadi konsesus kehujjah-an. Apabila kedua kaidah tersebut berlaku secara mandiri, tidak terjadi pembauran (tidak bersekutu) maka kehujjahan-nya ada dua ketentuan.

Pertama, kaidah ushul dalam penerapanya sebagai Takhrij alAhkam (mengeluarkan hukum dari sumbernya). Dalam hal ini, kaidah ushul digunakan untuk memudahkan persoalan yang berkaitan dengan pemahaman teks Inash. Semisal kaidah "amar" (al-amru lil wujub), kaidah "nahi" (an-Nahyu lil tahrimi) dan kaidah lain yang disinyalir sebagai kaidah ushul. Dalam kaidah ushul sering menghubungkan antara al-ashl (pokok) dan al-far'u (cabang) atau berhubungan dengan dalil-dalil umum. $^{19}$

Kedua, kaidah fiqh fungsinya adalah Tathbiq al-Ahkam yang penerapannya pada kasus-kasus yang timbul dalam kehidupan manusia. ${ }^{20}$ Dalam hal ini, kaidah fiqh secara praktis digunakan untuk menyelesaikan persoalan hukum. Kaidah yang demikian disinyalir dapat menduduki sebagai sumber hukum Islam. Dalam kaidah fiqh sering terjadi

18 Orang "safih" atau bodoh termasuk bagian dari 'awarid ahliyyah atau halhal yang menghalangi kemampuan mukallaf untuk bertindak hukum. Lihat Abu Rokhmad, Ushul Fiqh : Metodologi Ijtihad Hukum Islam, (Semarang: CV. Varos Mitra Utama, 2016), 153.

19 Said Aqil al-Munawwar, "Al-Qawaid al-Fiqiyyah dalam Perspektif Hukum

Islam”, al-Jami 'ah: Jurnal of Islamic Studies, No. 62/XII/1998, state Institut of Islam Studies( IAIN) Sunan Kali Jaga. 102.

${ }^{20}$ A. Djazuli, Kaidah-kaidah fikih: Kaidah-kaidah hukum Islam dalam menyelesaikan masalah-masalah yang praktis, (Jakarta: Kencana Prenada Media Group, 2006), 23. 
menghubungkan al-far' $u$ dengan al-far' $u$ yang memiliki kemiripan atau kumpulan hukum-hukum umum. ${ }^{21}$ Sebagian fuqaha menyebutnya, alAsybah wa an-Nadzair. ${ }^{22}$ Ketika al-qawaid al-fiqiyyah tanpa didukung teks/ nash tersebut, maka ulama sepakat menjadikan sebagai sumber hukum. ${ }^{23}$ Ini artinya kaidah tersebut sebagai manhaj al-Ijtihad yang setingkat dengan istihsan, istislah dan lainnya. Dalam mazhab Syafi'i, kehujjahan al-Qawa'id al-Fiqiyyah tidak terjadi khilafiyyah. Meskipun demikian secara umum dapat diklasifikasi dengan ketentuan: pertama, apabila kaidah tersebut bersifat universal(aghlabiyah) maka tidak ada kesepakatan bolehnya dijadikan sebagai sumber hukum, karena kebanyakan terdapat pengecualian (istitsna'). Semisal kaidah "at-Taabi'u taabi'un." Kedua, bila kaidah fiqh bersifat umum (kulli) maka dapat dijadikan sebagai sumber hukum sebagaimana nash, ijma dan qiyas. Semisal kaidah fiqh tentang hukum asal mua'amalah. Dalam mazhab Syafi'i, al-Qawaid al-Fiqiyyah dapat dijadikah hujjah dan sangat signifikan eksitensinya dalam fiqh. ${ }^{24}$ Dalam kitabnya al-Asybah wa anNadzair, al-Imam Jalaluddin as-Suyuthi as-Syafi'i menjelaskan ilmu alAsybah wa an-Nadzair adalah ilmu yang agung, dapat menyingkat hakikat, dasar-dasar dan rahasia fiqh, juga mempertajam analisis fiqh serta memberikan kemampuan dalam mengidentifikasi berbagai persoalan yang tak terhingga dengan melalui metode al-ilhaq wa at-Takhrij. ${ }^{25}$ Dengan demikian kaidah fiqh dapat dijadikan hujjah atau sumber hukum Islam.

\section{E. Kesimpulan}

1. Kaidah fiqh merupakan ilmu yang sangat menunjang dalam berbagai persoalan hukum. Terutama dalam fiqh mu'amalah. Kaidah tersebut membantu secara mekanis dalam masalah-masalah furu' yang serupa dan sama atau al-Asybah wa an-Nadzair. Untuk itu kaidah fiqh diformulasikan sebagai penyederhana dalam masalah furu' atau fiqiyyah yang memiliki kemiripan atau kesamaan hukum.

2. Kaidah fiqh fungsinya adalah Tathbiq al-Ahkam yang penerapannya pada kasus-kasus yang timbul dalam kehidupan manusia. Kaidah fiqh

${ }^{21}$ Said Aqil al-Munawwar, Al-Qawaid al-Fiqiyyah dalam Perspektif Hukum Islam, 102.

${ }^{22}$ A. Djazuli, Kaidah-kaidah fikih.., 7

${ }^{23}$ Said Aqil al-Munawwar, Al-Qawaid al-Fiqiyyah dalam Perspektif Hukum Islam, 109-110.

${ }^{24}$ Al-Bannani, Hasyiyah al-Bannaani, (Beirut: Dar al-Fikr, 1995), 357.

${ }^{25}$ Izuudin Ibn Abd a-Salam, Qawaidul Ahkam Fi Mashalih al-Anam, 5-7. 
juga disinyalir menduduki sebagai sumber hukum Islam. Dalam kaidah fiqh mencakup dan menghubungkan al-far'u dengan al-far' $u$ yang memiliki persamaan dan kemiripan.

3. Berdasarkan kajian diatas, kehujjahan kaidah fiqh: apabila al-qawa'id al-fiqiyyah tanpa didukung teks/ nash, maka ulama sepakat menjadikan sebagai sumber hukum. Meskipun demikian, kehujjahan kaidah tersebut dengan ketentuan: pertama, apabila kaidah tersebut bersifat universal (aghlabiyah) maka tidak ada kesepakatan dijadikan sebagai sumber hukum karena pasti terdapat pengecualian (istitsna'). Kedua, bila kaidah fiqh bersifat umum (kulli) maka dapat dijadikan sebagai sumber hukum sebagaimana nash, ijma dan qiyas. Kaidah yang kulli ini dalam mazhab Syafi'i disepakati dapat dijadikan sebagai sumber hukum.

\section{Daftar Pustaka}

Abu Rokhmad, Ushul Fiqh : Metodologi Ijtihad Hukum Islam, Semarang: CV. Varos Mitra Utama, 2016.

Abdullah bin Said Muhammad 'Ibadi, dhah al-Qawa'id al-Fiqiyyah, Jeddah, al-Haramain, tt.

Ahmad al-Nadawi, al-Qawaid al-Fiqhiyah, Cet. V, Beirut: Dar al-Qalam, 1998.

A. Djazuli, Kaidah-kaidah fikih: Kaidah-kaidah hukum Islam dalam menyelesaikan masalah-masalah yang praktis, Jakarta: Kencana Prenada Media Group, 2006.

Al-Imam Tajjuddin Abdul Wahab bin Ali bin Abdul Kafi as-Subki, alAsybah wa an-Nazhair, (Beirut: Dar al-Kutub al-Islamiyyah, tt ) Juz I.

Al-Suyuthi, Jalaluddin, Abd al-Rahman, al-Asybah wa an-Nazhair: Fi Qawaid wa Furu' fiqh asy-Syafi'i, cet. I, Beirut: Dar al-Kutub al-Ilmiyyah, 2012.

Al-Syahratsani, Al-Milal wa an-Nihal, Juz.i, (Mesir: Matba'ah Musthafa al-Babi al-Halabi wa Auladuh, 1967. 
Al-Bannani, Hasyiyah al-Bannaani, Beirut: Dar al-Fikr, 1995.

Asymuni A Rahman, Qaidah-qaidah fiqh, cet. I, Jakarta: Bulan Bintang, 1976.

DSN-MUI, Modul Pelatihan DPS Syariah Koperasi Syariah, Jakarta: tnp, 2018.

Ibnu Nuj'aim al-Hanafi, al-Asybah wa an-Nazhair Damaskus : Dar alFikri, 1983.

Izuudin Ibn Abd a-Salam, Qawaidul Ahkam Fi Mashalih al-Anam, tnp; Dar al-Jail, 1980.

Hasbi ash-Shiddiqie, Mabahits fi al-Qawai'd al-Fiqiyyah, Jakarta, tnp, tt. Jaih Mubarok, Sejarah dan Kaidah Asasi, cet. I, Jakarta: Raja Grafindo Persada, 2002.

Muhammad ibn Bahadur ibn Abdullah Badruddin al-Zarkasyi, AlManshur fi Tartib al-Qawaid fi al-Furu', ttp, tnp, tt.

Muhammad al-Ruki, Qawa'id al-Fiqh al-Islami, cet. I, Beirut: Dar alQalam, tt.

Muhammad Abu Zahrah, Ushul Fiqh ttp. Dar al-Fikri al-Arabi, tt.

M. Ma'shum Zainy al-Hasyimiy, Pengantar Memahami Nadzom alFaroidul Bahiyyah, Jombang: Darul Hikmah, 2010.

Said Aqil al-Munawwar, "Al-Qawaid al-Fiqiyyah dalam Perspektif Hukum Islam", al-Jami'ah :Jurnal of Islamic Studies, No. 62/XII/1998, state Institut of Islam Studies ( IAIN) Sunan Kali Jaga. 1998.

Syamsul Anwar, Argumentum a Fortiori dalam Metode Penemuan Hukum Islam, Studi Hukum Islam: Kajian Tematik Terhadap Persoalan Kontemporer, Jogjakarta: Fakultas Syari'ah Press UIN Sunan Kalijaga, 2008.

Qadhi Abd al-Wahhab al-Maliki, Al-Isyraf 'ala masa'il al-Khilaf, Tunis: Mathba'ah al-Iradah, t.t. 